\title{
THEONYMS IN THE HORROR STORY OF HOWARD PHILLIPS LOVECRAFT "IMPRISONED WITH THE PHARAOHS"
}

\author{
Hanna Kolosova \\ National Technical University of Ukraine “Igor Sikorsky Kyiv Polytechnic Institute”, Kyiv, Ukraine \\ plakyda@ukr.net
}

\begin{abstract}
This article is devoted to the research of features of the specific onomastic lexis for denotation of divine creatures and its usage in the literary genre of horrors on the example of Howard Phillips Lovecraft's short story "Imprisoned with the Pharaohs". In the centre of author's attention is the study of theonyms' influence, as a lexical instrument, on the formation of the atmosphere of horror and construction of specific text space of works of horror literature. Theonyms are proper names of deities in some pantheon which belongs to a certain religion or mythology. In this research, we assess the use of separate theonyms from the pantheon of religion of ancient Egypt. The term "theonym" describes the phenomena of the ideal world, which differs in the understanding of people. Theonymic peculiarity of words can show off while solving problems not only of linguistic character, but also philosophical, culturological etc. This article studies set of characteristics, which are typical in the literature of horror. Such features are optional for a genre, but absolutely necessary for the creation of the story which states the task to "frighten". Attention is focused on such characteristics: identity with the character, commonness of events, supersaturating of story with commonness, consequences of protagonist's decisions, complexity of timelines, possible but optional absence of ending, use of "strong" words for the festering of atmosphere. Horror features are described through the direct dependence of theonyms use, which strengthen the effect of "terrible" and put the accent on certain historic character of events.
\end{abstract}

Keywords: proper names; onyms, theonyms; horror literature; terror.

\section{Introduction}

Modern Ukrainian linguistics almost entirely overlooked the phenomenon of the literature of horror and lexical tools that help to create this genre. The detailed investigation of horror fiction as a genre of literature was carried out by different foreign scientists. For example, the profound research of American literature of horror was done by British writer and editor Brian Docherty in his book "American Horror Fiction: From Brockden Brown to Stephen King" with essays discussing such representatives of genre as Charles Brockden Brown, Edgar Allan Poe, Howard Phillips Lovecraft, Stephen King etc. (Docherty, 1990). An American writer Jason Colavito researches the genre of horror in his works such as "Knowing Fear: Science, Knowledge, and the Development of the Horror Genre", exploring the "intimate" connection between horror fiction and science (Calavito, 2008). His collection of essays "Horror \& Science: Essays on the Horror Genre, Skepticism, and Scientology" studies the correlation between reason and fear, including the works by skeptical writers who blame horror stories in being dangerous and having a pernicious influence (Calavito, 2011). The work of British science fiction writer Brian Michael Stableford "Historical Dictionary of Fantasy Literature" includes the chronology that demonstrates the evolution of fantasy, including horror, from its origins to the modern times (Stableford, 2005). In general, horror fiction as an independent cultural field exists for more than three centuries, being the branch of "macabre" science fiction, studied by different linguists and writers. Despite the fact that the genre of horror is presented with a huge number of outstanding works, neither literature nor any other science related to linguistic and stylistic analysis of literary works pays sufficient attention to the lexical instruments of this phenomenon. The aim of this article is to understand the place and role of such specific lexical tools as proper names (PN) or onyms, namely theonyms, in the literary horror genre. The material of our study is a short story written by Howard Phillips Lovecraft "Imprisoned with the Pharaohs".

The object of the article is the functioning of specific lexical tools in the literary genre of horror.

The subject of this article is a special type of onyms - theonyms that represent proper names of gods in any pantheon, that is, the group of gods or saints that belong to a particular religion or mythology. Most of the proper names have a rich lexical background, fixed in people's memory as rigid associationspersonalities. These personalities may be fixed in people's mind as myths and legends. They might be the myths about historical events or heroes, fiction characters, gods of some pantheon etc. The people's association is extremely important. Due to that, it is necessary to study any language along with the historical events (Bashmakova, 2015, p. 44). Since the term "theonym" describes the phenomena of the perfect world, the degree of reality, which is not the same in understanding of different people, theonyms property of words can be manifested while solving problems not only of linguistic nature, but also philosophical, cultural and other. Theonyms are considered as a subgroup of mythonyms and are quite clearly represented in the polytheistic religions (the belief in multiple gods) (Superanskaya, 1978, pp. 180-181). The Lovecraft's story "Imprisoned with the Pharaohs" contains the names of the deities from the Pantheon of ancient Egypt. 
Therefore can be formed the task of our research, namely, the need to understand the issue: how does the author try to create an atmosphere of fear in his story with the help of theonyms?

\section{Horror fiction as a genre of literature}

There is the need to understand what constitutes the horror fiction. The direct meaning of the word "horror" is "fear". This word is often used in connection with the literature of mystery. According to Parfenov (2013), it is a mistake to assume horror as a "subgenre" of fantasy, because fantasy, as a basic element of fiction, is not mandatory to horror, as well as the mystical element. That is why the name of the genre "literature of horror and mystery" contains the word "and", which can be understood as "and/or". The mystical, the fantastic, the grotesque is often found in horrors, but not always (Parfenov, 2013). In the Lovecraft's story the mystical element is rather obvious, because the whole story is about the visit of the famous magician to Egypt and his meeting with the unknown horror. If we assume the beliefs of the ancient Egyptians and their deities as an absolute fiction, the fantastic element is amplified by the use of theonyms. After all, it is generally accepted that theonyms are a part of mythonyms that are opposed to realonyms (objects of reality).

On the contrast to Parfenov, Stableford (2005) mentions that supernatural horror fiction is definitely a subcategory of the fantasy rather than the category of the science fiction, with which it may be correlated in the critical literature under such term as "supernatural fiction". The term "dark fantasy" or "Gothic fiction" sometimes is used as "quasi-euphemistic substitute" to "horror literature", although it includes both elements of horror and fantasy (Stableford, 2005, p. 97). The word "horror" is a term used to label the genre for commercial purposes, because unlike the other genre labels it shows up the intended effect of work rather than its thematic content. Of course, fundamental distinctions between fantasy and horror fiction should be drawn, notwithstanding its complexity. Nevertheless, even the noblest high fantasy is not totally deprived of the horror elements. The author claims that horror fiction as a commercial phenomenon is a subcategory of the contemporary fantasy, and "leftovers" of the historical fantasy, but it is necessary to distinguish the two for special critical consideration, because the relationship between the fantasy elements and naturalistic ones is obvious. Horror fiction achieves its universal position from the contrast between unpredictable intrusions and "normality". At the same time, fantasy is primarily understood in terms of secondary worlds, being on the borders of the genre rather than at the core (Stableford, 2005, p. 204).

Different sources define horror as a genre of literature, whose goal is the creation of fear, of something terrible, disgust in the audience of readers - in other words, creating an atmosphere of terror. However, it is not necessary for the text to be horror only because of the presence of such "horrible" images as zombies or vampires. For example, popular among a certain audience the novels of Stephanie Meyer clearly show that werewolves and other typical horrible creatures, the incarnations of evil, can become characters of the fantasy-melodrama (Parfenov, 2013). In "Imprisoned with the Pharaohs" throughout the story until almost the very end there is no "terrible" creatures in reality, but only in words, as a part of Egypt's history:

"The red sun sank low, bringing the relentless chill of Egyptian dusk; and as it stood poised on the world's rim like that ancient god of Heliopolis - Re-Harakhte, the Horizon-Sun - we saw silhouetted against its vermeil holocaust the black outlines of the Pyramids of Gizeh - the palaeogean tombs there were hoary with a thousand years when TutAnkh-Amen mounted his golden throne in distant Thebes. Then we knew that we were done with Saracen Cairo, and that we must taste the deeper mysteries of primal Egypt - the black Kem of Re and Amen, Isis and Osiris. " (Lovecraft, 2015, p. 6)

In this passage, there are five theonyms, namely, Re-Harakhte, Kem of Re, Amen, Isis, Osiris. The author has no intention to scare the reader with such names. The main goal is the creation of an atmosphere of historicity and authenticity of current events. Such effect may also be achieved by adding historical dates and names of the real historical personalities:

"The pyramids stand on a high rock plateau, this group forming next to the northernmost of the series of regal and aristocratic cemeteries built in the neighborhood of the extinct capital Memphis, which lay on the same side of the Nile, somewhat south of Gizeh, and which flourished between 3400 and 2000 B.C. The greatest pyramid, which lies nearest the modern road, was built by King Cheops or Khufu about 2800 B.C., and stands more than 450 feet in perpendicular height. In a line southwest from this are successively the Second Pyramid, built a generation later by King Khephren, and though slightly smaller, looking even larger because set on higher ground, and the radically smaller Third Pyramid of King Mycerinus, built about 2700 B.C." (Lovecraft, 2015, pp. 6-7)

If the reader begins to feel a certain authenticity of the story, fear becomes closer and much more real.

In horror such standard elements as a certain kind of characters (in our case deities), chronotope (the ancient pyramids of Giza), topics (the afterlife, meeting with paranormal), the plot course (descent into the 
dungeon of the pyramid), the elements of fiction (meeting with the dead), detective or even fairy tales are the means through which an author consciously or unconsciously tries to achieve his goal. The goal is to scare the reader.

Lovecraft (1936) described fear: "The oldest and strongest emotion of mankind is fear, and the oldest and strongest kind of fear is fear of the unknown" (Lovecraft, 1984, p. 725). It is important to understand that the word "fear" means all palette of feelings and emotions related to fear - from the "low" disgust and banal fear of pain, to "high" and the existential "cosmic" (the term of Lovecraft) horror, from specific phobias, such as fear of spiders, to the absurd night horror, or a dark Gothic atmosphere (Parfenov, 2013).

\section{Horror genre origins}

Horror emerged as the genre even earlier than the works of such classics of the genre as Mary Shelley, Bram Stoker, Edgar Allan Poe etc. Scary element manifests itself in the folklore of various countries of the world, like in the fairy tales and folk songs (for example, in the Scottish ballads, filled with death, madness, despair). Horrible elements can be found in medieval tales of chivalry. The first exclusively written form of horror should be considered a Gothic novel, which as a phenomenon of the pseudo-romanticism largely influenced the further works of romantics. During the popularity of the Gothic novel, the horror genre was divided into two branches, "sentimental" and "frenetic". They signify two completely different approaches to the implementation of artistic tasks "inspiration of fear". Anna Radcliffe distinguished between the two kinds of horror: terror - generated by the contemplation of wild, unusual, stimulating imagination, and the horror itself - the fear in real life. The first one awakens imagination, fosters the fear, the second, on the contrast, "kills" imagination, shocking the reader with the scenes of death, violence, the terrible strain and so on (Parfenov, 2013).

As long as there have existed stories about something supernatural, some people believed that the terrible creatures described in them may be real. There has always been the doubt about the reality of the supernatural monsters by skeptics. Mythological creatures such as dragons and unicorns were once thought to live in forests and mountains. Even modern fantastic creatures like Bigfoot or the Loch Ness monster have their supporters. These stories were interpreted as non-fiction. At the end of the Enlightenment emerged such type of fiction as the tale of supernatural terror. Unlike the narrators of myths and legends, the authors of these stories knew they were creating the pure fiction. However, critics claimed that the stories were not safe, especially for those, who may come to believe in superstitious tales (Calavito, 2011, p.12).

Working directly with the emotion of fear, horror writers use sources, images, embodiment of fear as a specific literary tool. Introducing such tools in the literary system of the genre is an attempt to further its aesthetic side. Therefore, the use of such specific PN as theonym helps to create fairly detailed ideas about the Pantheon of gods of ancient Egypt, thereby reinforcing the atmosphere of unknown terror.

Determining the place of the genre of horror and mystery in the genres of mass literature, it should be noted its proximity to the thriller and the detective. "The Hound of the Baskervilles" of Conan Doyle or "Ten Little Niggers" of Agatha Christie can be considered very close to the horror, being both a timeless classic and a benchmark of the detective genre. It is often quite difficult to distinguish thriller from the horror. At the same time, elements of horror, its typical characters and images, constantly invade into the other genres of popular literature, including science fiction and fantasy. Component of thriller in "Imprisoned with the Pharaohs" is the kidnapping of the hero by the locals and his attempt to understand the purpose of such heinous acts, enhanced by the fear of unpredictable consequences of such situation. The atmosphere of thriller is also provoked due to the similarity of the main villain, who organised the kidnapping, with the Sphinx:

"Perhaps, I thought, he resented that odd reproduction of the Sphinx's half-smile which I had often remarked with amused irritation; or perhaps he did not like the hollow and sepulchral resonance of Abdul's voice." (Lovecraft, 2015, p. 10)

"I thought of how much my hollow-voiced guide Abdul Reis looked like an old Egyptian priest or Pharaoh or smiling Sphinx ... and wondered." (Lovecraft, 2015, p. 12)

"Then the dream faces took on human resemblances, and I saw my guide Abdul Reis in the robes of a king, with the sneer of the Sphinx on his features. And I knew that those features were the features of Khephren the Great, who raised the Second Pyramid, carved over the Sphinx's face in the likeness of his own and built that titanic gateway temple whose myriad corridors the archaeologists think they have dug out of the cryptical sand and the uninformative rock." (Lovecraft, 2015, p. 12)

That is why, the further, the more a villain is similar to the fantastic entity that would not exist in the modern world. 


\section{Functioning of theonyms in the text}

Lexical cohesion involves a selection of lexical items. There is a substantial freedom of choice, for the use of a certain lexical unit may be determined by the stylistic features of a text or the author's intention (Matkovska, 2015, p. 74). Loginov (1998) proposes a specific set of characteristics that are typical to the literature of horror, mentioning that they are not generally accepted standards of horror, but absolutely necessary for the creation of a truly terrible work. We relate the use of theonyms, where appropriate, with the characteristics of "terrible" in the works:

1) Identity of reader and character. A reader has to identify himself with the hero of the story. This character may not remind the reader or even to be human (Loginov, 1998, p. 4). In the case of "Imprisoned with the Pharaohs", the main character is a world-famous magician, the prototype of which is Harry Houdini (Joshi, 2004, p. 60). The story is told in the first person, therefore the main character acts as a narrator. In this case, it is easier for the reader to identify himself with the hero of the story:

"Ever since the wide appearance of $\boldsymbol{m y}$ name as a performer of unexplained feats, $\boldsymbol{I}$ have encountered strange narratives and events which my calling has led people to link with my interests and activities... Many of these matters I have told and shall continue to tell very freely; but there is one of which I speak with great reluctance, and which $\boldsymbol{I}$ am now relating only after a session of grilling persuasion from the publishers of this magazine, who had heard vague rumors of it from other members of my family." (Lovecraft, 2015, p. 3) "What it did was to herald my identity wherever I subsequently went, and deprive my wife and me of all the placid inconspicuousness we had sought. Traveling to seek curiosities, I was often forced to stand inspection as a sort of curiosity myself!" (Lovecraft, 2015, p. 4)

The saturation of the text with the first-person pronouns $I$, we and $m y$ helps the reader to identify all events with himself. Along with the narrator the images of bearers of theonym names appear all the time: "Then we knew that we were done with Saracen Cairo, and that we must taste the deeper mysteries of primal Egypt - the black Kem of Re and Amen, Isis and Osiris." (Lovecraft, 2015, p. 6)

In such episodes we can see the combination of "normality" and "abnormality", in other words, intrusion of the reader into the fiction world.

2) Ordinariness of what is happening. The horrors that happen in exotic circumstances usually do not scare readers. It is difficult to associate oneself with the brave traveler, who travels around the Amazon. When the hero is attacked by an anaconda, the reader sees it as another adventure, not as something terrible that causes tremors. It is quite another issue, when the same anaconda appears in your apartment, disturbing the quiet flow of life (Loginov, 1998, p. 5). Characteristic of the "everyday" events is not typical to the story of H. P. Lovecraft, because the situation takes place in Egypt: "We had come to Egypt in search of the picturesque and the mystically impressive, but found little enough when the ship edged up to Port Said and discharged its passengers in small boats. Low dunes of sand, bobbing buoys in shallow water, and a drearily European small town with nothing of interest save the great De Lesseps statue, made us anxious to get to something more worth our while. After some discussion we decided to proceed at once to Cairo and the Pyramids, later going to Alexandria for the Australian boat and for whatever Greco-Roman sights that ancient metropolis might present." (Lovecraft, 2015, p. 4). The constant use of names of ancient deities also deprives the work routine. However, if reader associates himself with the tourist, who visited this exotic country, the element of "routine" can show off itself to some extent.

3) Oversaturation of text with routine can also negatively affect its perception. Such texts transform into the everyday stories with a small number of "terrible" events. This is due to the fact that the reader cannot be kept too long in suspense, so author has to intrude subtopics. The ideal variant for the horror genre is a short story. An appropriate form will be a short preamble that reflects the familiar environment and familiar people, in which suddenly interferes something that scares the reader, then the story ends (Loginov, 1998, p. 5). "Imprisoned with the Pharaohs" is actually a small story about a tourist trip to Egypt interfered with the element of surprise in the form of kidnapping of the protagonist:

"Suddenly something happened which in a flash proved the correctness of my reflections and made me curse the denseness whereby I had accepted this night's events as other than the empty and malicious 'frameup' they now showed themselves to be. Without warning, and doubtless in answer to some subtle sign from Abdul, the entire band of Bedouins precipitated itself upon me; and having produced heavy ropes, soon had me bound as securely as I was ever bound in the course of my life, either on the stage or off." (Lovecraft, 2015, p. 12)

"It was the ecstasy of nightmare and the summation of the fiendish. The suddenness of it was apocalyptic and demoniac - one moment I was plunging agonizingly down that narrow well of milliontoothed torture, yet the next moment I was soaring on bat-wings in the gulfs of hell; swinging free and swooping through illimitable miles of boundless, musty space; rising dizzily to measureless pinnacles of 
chilling ether, then diving gaspingly to sucking nadirs of ravenous, nauseous lower vacua..." (Lovecraft, 2015, pp. 13-14)

It is a mistake to say that the story is overloaded with routine, because irregularity of the situation (suddenly, without warning, suddenness, one moment... yet the next moment) and constant use of theonym names make the text closer to the fantastic and further from everyday novel.

4) "Guilt" of the character. This does not mean that the main character gets what he deserves; however, the impetus for the beginning of the event must be contributed by certain actions of the character. Due to one careless movement of the protagonist, which leads to further events, his self-preservation instinct begins to appear especially bright. The reader feels particularly uncomfortable reading such type of texts. Even in the cases where the fatal end is conceived from the very beginning, a reader still thinks that the victim caused trouble with some careless action. The "guilt" of the character leads to two consequences: a) the inevitability of the terrible thing that was caused by the initial act; b) the moral doom of the character. That is, the hero of the story, without being doomed by fate and having the chance to escape, however, becomes doomed by the circumstances. It may seem that the difference almost does not matter; however, here appears the thin line that separates complete hopelessness from hope of sentenced to death person for a pardon at the last second. The person in despair is quite difficult to scare (Loginov, 1998, p. 6). The character of the story of H. P. Lovecraft makes a mistake choosing as a guide some random person, not an official representative of the hotel, and later he regrets:

"Not until afterward did I see that I should have applied at the hotel for a licensed guide. This man, a shaven, peculiarly hollow-voiced and relatively cleanly fellow who looked like a Pharaoh and called himself 'Abdul Reis el Drogman' appeared to have much power over others of his kind; though subsequently the police professed not to know him, and to suggest that reis is merely a name for any person in authority, whilst 'Drogman' is obviously no more than a clumsy modification of the word for a leader of tourist parties - dragoman." (Lovecraft, 2015, pp. 4-5)

The following fatal mistake of the character was his proposal to become the second in the fight of his guide Abdul Reis with local Beduin:

"In all this planning there was much which excited my interest. The fight itself promised to be unique and spectacular, while the thought of the scene on that hoary pile overlooking the antediluvian plateau of Gizeh under the wan moon of the pallid small hours appealed to every fiber of imagination in me. A request found Abdul exceedingly willing to admit me to his party of seconds; so that all the rest of the early evening I accompanied him to various dens in the most lawless regions of the town-mostly northeast of the Ezbekiyeh - where he gathered one by one a select and formidable band of congenial cutthroats as his pugilistic background." (Lovecraft, 2015, p. 10)

In this case, the erroneous actions lead to the inevitability of the further terrible events, namely the kidnapping of the main character, lowering it to the bottom of the pyramid and everything that happens next. Somehow, such kind of situation may be connected to fate. Fate is an individual development pattern in the course of the lifetime. It is a course of events or a set of circumstances that is beyond the control of the person. Fate is one the most mysterious beginnings of our life (Gryshchenko, 2016, p. 81).

5) Complexity of the time frames. On the one hand, horror is always sudden, and on the other hand nothing enhances fear like a long wait. Both of these tendencies are presented in the literature of horror. Certainly, the narrowly outlined genre requires for the accomplishing of its tasks the use of specific literary methods. The languid flow of the time does not maintain an authorial expression. The literature of horrors "perishes" immediately, as soon as a careless author begins to pile up one horror on other. Authentic fear is always unique (Loginov, 1998, p. 7). "Imprisoned with the Pharaohs" provides the atmosphere of terror that gradually escalates due to saturation of the text with teonynms, creating a picture of ancient Egypt and the idea of the Pantheon of gods. The more often mentioned the names such as Horus, Anubis and others, the closer author brings reader to the final scene, where fantasy characters are going to feed some creature that, in the opinion of the main character, is an epitome of the top of someone from the Pantheon of Egyptian gods. However, this "who" is the most terrible of all theonym names owners:

"It occurred to me that, judging from the elaborateness of this worship, the concealed deity must be one of considerable importance. Was it Osiris or Isis, Horus or Anubis, or some vast unknown God of the Dead still more central and supreme? There is a legend that terrible altars and colossi were reared to an Unknown One before ever the known gods were worshipped... " (Lovecraft, 2015, p. 24)

The main character names the creature as Unknown. Therefore, to actually recorded in historical sources names from the Pantheon of Egyptian gods is added artificially created theonym. Actually, "terrible" creature appears almost at the end of the story, and its appearance is preceded by a fairly long wait. However, the appearance of the being is totally unexpected for the reader: 
"It was something quite ponderous, even as seen from my height; something yellowish and hairy, and endowed with a sort of nervous motion. It was as large, perhaps, as a good-sized hippopotamus, but very curiously shaped. It seemed to have no neck, but five separate shaggy heads springing in a row from a roughly cylindrical trunk; the first very small, the second good-sized, the third and fourth equal and largest of all, and the fifth rather small, though not so small as the first. Out of these heads darted curious rigid tentacles which seized ravenously on the excessively great quantities of unmentionable food placed before the aperture. Once in a while the thing would leap up, and occasionally it would retreat into its den in a very odd manner. Its locomotion was so inexplicable that I stared in fascination, wishing it would emerge farther from the cavernous lair beneath me." (Lovecraft, 2015, pp. 25-26)

Therefore, there is a combination of the gradual forcing of the atmosphere with the sudden appearance of substance - the bearer of theonym name.

6) Absence of the end is fairly typical to horror. Formally, the end can be of any type: a character may die, or may be saved - all this is irrelevant to the goal of story - to scare the reader (Loginov, 1998, p. 8). The end of "Imprisoned with the Pharaohs" is open: "But I survived and I know it was only a dream" (Lovecraft, 2015, p. 26). The hero believes that all the events were a dream, however, notes that he survived. Consequently, he did not fully believe that it was only a dream. The ending can be considered as a conclusion that he makes about the creature he sees:

"The Great Sphinx! God! - that idle question I asked myself on that sunblest morning before ... what huge and loathsome abnormality was the Sphinx originally carven to represent? Accursed is the sight, be it in dream or not, that revealed to me the supreme horror - the unknown God of the Dead, which licks its colossal chops in the unsuspected abyss, fed hideous morsels by soulless absurdities that should not exist. The five-headed monster that emerged ... that five-headed monster as large as a hippopotamus ... the fiveheaded monster - and that of which it is the merest forepaw..." (Lovecraft, 2015, p. 26)

In other words, the character thinks that a terrible creature the size of a hippopotamus, which he saw, was only the front paw of the giant monster. To put it in a nutshell, the scariest moment of the Lovecraft's story is the final scene, which describes the bearer of the theonym name Unknown.

7) Inappropriate may be the use of "strong words", such as "suddenly", "scary", "terrible" etc. These words warn the reader that he is going to be scared. Since there is no real danger in the process of reading, further efforts to scary become useless. In some cases, such words and expressions may refer to something completely minor, being used in the context, gradually begin to affect the psyche of the reader (Loginov, 1998, p.8). Lovecraft quite frequently uses the "strong" words in the story. They may serve as the adjectives to describe the secondary elements, like the terrible events, terrible gateway temple, horrible way and others:

"The precise nature of these dreams was very clear while I was experiencing them, but became blurred in my recollection almost immediately afterward, and was soon reduced to the merest outline by the terrible events - real or imaginary - which followed. " (Lovecraft, 2015, p. 14),

"And I looked at the long, lean rigid hand of Khephren; the long, lean, rigid hand as I had seen it on the diorite statue in the Cairo Museum - the statue they had found in the terrible gateway temple - and wondered that I had not shrieked when I saw it on Abdul Reis...” (Lovecraft, 2015, p. 15), “...and the obscure and portentous ka or life-principle which wandered about the upper and lower worlds in a horrible way, demanding occasional access to the preserved body..." (Lovecraft, 2015, pp. 17-18)

Moreover, these "strong" adjectives are also used to describe the main creature - bearer of the theonym name, for instance, supreme horror, hideous, loathsome abnormality etc.: "That question, so innocent and whimsical then, assumed in my dream a meaning of frenetic and hysterical madness ... what huge and loathsome abnormality was the Sphinx originally carven to represent?" (Lovecraft, 2015, p. 18)

\section{Conclusion}

Study of such complex object as a literature of horror is now at its initial stage in the Ukrainian linguistic and literary criticism. Definition of the role and place of lexical tools in the genre of horror is an important task for modern researchers. Such specific lexical tool as theonyms (the subgroup of mythonyms) helps to realise the main goal of horror story - to scare the reader. Moreover, certain theonyms foster the approximation of the main character's story to a certain historicity of events, conveying of nontrivial atmosphere, complication of the time frames with the correlation of past and present etc. The research prospects may involve the study of functioning of different types of proper names as specific tools for text building in the genre of horror fiction. 


\section{References:}

Bashmakova, I. S. (2015). English idioms with proper name in semiotic aspect. "East West” Association for Advanced Studies and Higher Education GmbH, 9-10, 44-46.

Calavito, J. (2008). Knowing Fear: Science, Knowledge, and the Development of the Horror Genre. Jefferson, NC: McFarland \& Company.

Calavito, J. (2011). Horror \& Science. Essays on the Horror Genre, Skepticism, and Scientology. Retrieved March 20, 2017, from http://www.jasoncolavito.com

Docherty, B. (1990). American Horror Fiction: From Brockden Brown to Stephen King. New York: St. Martin's. https://doi.org/10.1007/978-1-349-20579-0

Gryshchenko, Y. (2016). The concept of fate in American science fiction literature. Advanced education, 5, 80-84. https://doi.org/10.20535/2410-8286.66886.

Joshi, S. T. (2004). An H.P. Lovecraft Encyclopedia. Westport, Connecticut: Greenwood Publishing Group.

Loginov, S. (1998). Kakoy uzhas! [How scarry!]. Anyzotropnoe Shosse, 2, 5-9.

Lovecraft, H. P. (1984). The Haunter of the Dark (1936) in The Dunwich Horror and Others, S. T. Joshi (ed.). Sauk City, WI: Arkham House.

Lovecraft, H. P. (2015). Imprisoned with the Pharaohs. South Australia: The University of Adelaide.

Matkovska, H. O. (2015). Linguistic devices of developing text formal integrity. Advanced education, 3, 70-76. https://doi.org/10.20535/2410-8286.44296

Parfenov, M. S. (2013). Horror, uzhasyi, uzhastiki... Mifyi i pravda zapretnogo zhanra [Horror, terror, chillers ... Myths and truth of forbidden genre]. DARKER, 12. Retrieved September 10, 2016, from http://darkermagazine.ru/page/horror-uzhasyuzhastiki-mify-i-pravda-zapretnogo-zhanra

Stableford, B. (2005). Historical Dictionary of Fantasy Literature. Plymouth, England: Scarecrow Press.

Superanskaya, A. V. (1978). Obschaya teoriya imeni sobstvennogo [General theory of proper name]. Moscow, Russia: Nauka.

Received: October 04, 2016

Accepted: September 25, 2017 